\title{
Amycolicicoccus subflavus gen. nov., sp. nov., an actinomycete isolated from a saline soil contaminated by crude oil
}

\author{
Correspondence \\ Xiao-Lei Wu \\ xiaolei_wu@pku.edu.cn
}

\author{
Ya-Nan Wang, ${ }^{1,2}$ Chang-Qiao Chi, ${ }^{1}$ Man Cai, ${ }^{1}$ Zhi-Ying Lou, ${ }^{1}$ \\ Yue-Oin Tang, ${ }^{1}$ Xiao-Yang Zhi, ${ }^{3}$ Wen-Jun $\mathrm{Li}^{3}{ }^{3}$ Xiao-Lei Wu ${ }^{1}$ and Xun Du ${ }^{2}$ \\ ${ }^{1}$ Department of Energy and Resources Engineering, College of Engineering, Peking University, \\ Beijing 100871, PR China \\ ${ }^{2}$ Key Laboratory of Microbial Engineering at the Institute of Biology, Henan Academy of Sciences, \\ Zhengzhou 450008, PR China \\ ${ }^{3}$ The Key Laboratory for Microbial Resources of the Ministry of Education, Laboratory for \\ Conservation and Utilization of Bio-Resources, Yunnan Institute of Microbiology, Yunnan \\ University, Kunming, Yunnan 650091, PR China
}

The suborder Corynebacterineae was first described by Stackebrandt et al. (1997) and comprises seven families, Nocardiaceae, Gordoniaceae, Tsukamurellaceae, Dietziaceae, Corynebacteriaceae, Mycobacteriaceae (Stackebrandt et al., 1997) and Segniliparaceae (Butler et al., 2005). Each family encompasses one genus, except Nocardiaceae, which contains the genera Nocardia and Rhodococcus, and Gordoniaceae, which contains the genera Gordonia, Millisia (Soddell et al., 2006) and Skermania. Currently, the suborder Corynebacterineae comprises these 10 genera and another genus, Williamsia (Kämpfer et al., 1999). Members of these genera form distinct lineages in the phylogenetic tree based on $16 \mathrm{~S}$ rRNA gene sequences. Almost all members of the suborder Corynebacterineae contain mycolic acids, except for Corynebacterium amycolatum (Collins et al., 1988), Corynebacterium atypicum

The GenBank/EMBL/DDBJ accession numbers for the 16S rRNA gene sequences of strains DOS3-9A $1^{\top}$ and DOS3-9A2 are EF564379 and FJ882017, respectively.
(Hall et al., 2003), Corynebacterium caspium (Collins et al., 2004), Corynebacterium ciconiae (Fernández-Garayzábal et al., 2004), Corynebacterium kroppenstedtii (Collins et al., 1998), Corynebacterium minutissimum, Corynebacterium striatum and Corynebacterium xerosis (Wauters et al., 1996).

Strains DQS3-9A1 ${ }^{\mathrm{T}}$ and DQS3-9A2 were isolated from a saline soil contaminated with crude oil in the Shengli Oilfield of eastern China by 10 -fold dilution plating on agar plates containing only oil-produced water at $30{ }^{\circ} \mathrm{C}$ for 7 days. The two isolates were purified and incubated on plates of artificial seawater (ASW) agar $\left(1^{-1}\right.$ : peptone, $5 \mathrm{~g}$; yeast extract, $1 \mathrm{~g} ; \mathrm{Na}_{2} \mathrm{SO}_{4}, 4 \mathrm{~g} ; \mathrm{KCl}, 0.68 \mathrm{~g} ; \mathrm{KBr}, 0.1 \mathrm{~g}$; $\mathrm{H}_{3} \mathrm{BO}_{3}, 0.025 \mathrm{~g} ; \mathrm{MgCl}_{2} . \mathrm{H}_{2} \mathrm{O}, 5.4 \mathrm{~g} ; \mathrm{CaCl}_{2} .2 \mathrm{H}_{2} \mathrm{O}, 1.5 \mathrm{~g}$; $\mathrm{SrCl}_{2} .6 \mathrm{H}_{2} \mathrm{O}, 0.024 \mathrm{~g} ; \mathrm{NaHCO}_{3}, 0.2 \mathrm{~g} ; \mathrm{Na}_{2} \mathrm{HPO}_{4}, 0.04 \mathrm{~g}$; $\mathrm{NH}_{4} \mathrm{Cl}, 0.5 \mathrm{~g} ; \mathrm{NaF}, 0.002 \mathrm{~g} ; \mathrm{pH} 8.0$ ) with $2.4 \% \mathrm{NaCl}$ (Eguchi et al., 1996) for 2 days at $30^{\circ} \mathrm{C}$. Growth was assessed at different temperatures $\left(5-50{ }^{\circ} \mathrm{C}\right), \mathrm{pH}$ values $(2.0-12.0)$ and salinity $(0-20 \%, \mathrm{w} / \mathrm{v}, \mathrm{NaCl})$. The $\mathrm{pH}$ tolerance was examined in ASW medium containing $5 \%$ 
(w/v) $\mathrm{NaCl}$ at $30{ }^{\circ} \mathrm{C}$. The $\mathrm{NaCl}$ concentration required for growth was investigated between 0 and $20 \%(\mathrm{w} / \mathrm{v})$ in ASW medium at $\mathrm{pH} 7.0$ and $30{ }^{\circ} \mathrm{C}$.

Morphological characteristics of strain DQS3-9A1 ${ }^{\mathrm{T}}$ were examined using scanning electron microscopy. Denitrification was assessed using a previously described method (Zumft, 1991). Hydrolysis of starch, gelatin and Tween 80 , along with urease activity and carbon source utilization, were examined according to Williams et al. (1983) on ASW medium after 5-7 days incubation at $30{ }^{\circ} \mathrm{C}$. Cellular fatty acid methyl esters were prepared and analysed using gas chromatography according to the instructions of the Microbial Identification System (MIDI). Fatty acid analysis was performed using the Sherlock system (Microbial ID). Isoprenoid quinones were analysed using HPLC with a reversed-phase column (Shim-pack, VPODS; Shimazu) as described by Komagata \& Suzuki (1987). Polar lipids were extracted and examined by one- and two-dimensional TLC on Merck silica gel 60 F254 aluminium-backed thin-layer plates according to the procedures described by Kates (1986) and Collins et al. (1980).

Extraction of genomic DNA and PCR amplification of the $16 \mathrm{~S}$ rRNA gene were done as described by Wang et al. (2007). The G+C content of genomic DNA was determined by thermal denaturation (Marmur \& Doty, 1962) with DNA from Escherichia coli K-12 as a control. DNA-DNA hybridization was carried out in triplicate following the methods of De Ley et al. (1970) and Huß et al. (1983). The 16S rRNA gene sequence was compared to sequences obtained from public databases (GenBank/ EMBL/DDBJ) to find the most closely related species. Phylogenetic analysis was performed using the software package MEGA version 3.1 (Kumar et al., 2004) after multiple sequence alignment with CLUSTAL_X (Thompson et al., 1997). A phylogenetic tree was constructed with the neighbour-joining method (Saitou \& Nei, 1987) based on a distance matrix that was corrected by Kimura's twoparameter model (Kimura, 1980). Bootstrap analysis with 1000 resamplings was used to evaluate the robustness of the tree's topology (Felsenstein, 1985).

Both strain DQS3-9A1 ${ }^{\mathrm{T}}$ and strain DQS3-9A2 were Grampositive cocci. The cells of strain DQS3-9A1 ${ }^{\mathrm{T}}$ were $0.7-$ $0.9 \times 0.9-1.05 \mu \mathrm{m}$ without a flagellum (Fig. 1). Neither strain formed spores. The colonies of the two strains were dry, opaque and light-yellowish white on ASW agar. Their growth occurred at $15-42{ }^{\circ} \mathrm{C}$, pH $6.0-11.0$ and in $1-12 \%(\mathrm{w} / \mathrm{v})$ $\mathrm{NaCl}$. Tests of strains DQS3-9A1 ${ }^{\mathrm{T}}$ and DQS3-9A2 for hydrolysis of starch, gelatin, Tween 80 and casein, production of indole and DNase, aerobic nitrite reduction and anaerobic nitrate reduction were negative, whereas tests for hydrogen sulfide production and aerobic nitrate reduction were positive. The utilization pattern of sole carbon and nitrogen sources of strains DQS3-9A1 $1^{\mathrm{T}}$ and DQS3-9A2 was identical. Detailed physiological characteristics of isolate DQS3-9A $1^{\mathrm{T}}$ are given in the species description.

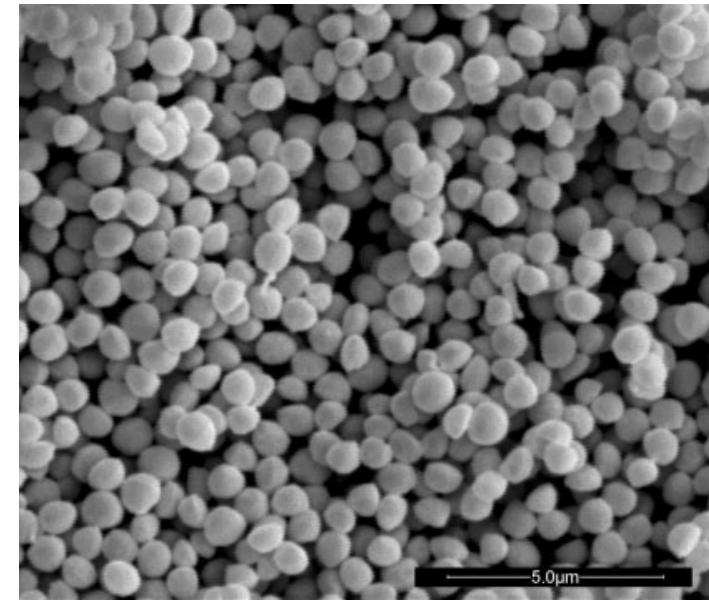

Fig. 1. Scanning electron micrograph of negatively stained cells of strain DQS3-9A $1^{\top}$.

The almost-complete 16S rRNA gene sequences of strains DQS3-9A1 ${ }^{\mathrm{T}}$ and DQS3-9A2 were obtained. In the phylogenetic tree (Fig. 2), the two strains clustered in a distinct clade that was strongly supported by the high bootstrap value $(100 \%)$, and the clade could be equated with branches corresponding to recognized genera. The strains tested were most closely related to recognized Mycobacterium species (92.7-94.9\% similarities). Additionally, the major sugars in the cell wall of the two strains were arabinose and galactose, also supporting the affiliation of the isolates to the family Mycobacteriaceae. The predominant menaquinones of strain DQS3-9A ${ }^{\mathrm{T}}$ were MK-8 (85.5\%) and MK-7 (8.0\%), and the major cellular fatty acids were $\mathrm{C}_{16: 0}(20.5 \%), 10$-methyl $\mathrm{C}_{17: 0}$ (19.3\%), 10-methyl $\mathrm{C}_{18: 0}(16.1 \%)$, summed feature 3 $(11.4 \%), \mathrm{C}_{15: 0}(11.3 \%), \mathrm{C}_{17: 0}(5.0 \%)$ and $\mathrm{C}_{17: 1} \omega 8 \mathrm{c}$ $(5.0 \%)$. The patterns of the predominant menaquinones and major cellular fatty acid composition of strain DQS39A2 were identical to those of strain DQS3-9A1 ${ }^{\mathrm{T}}$. The polar lipids of strain DQS3-9A1 ${ }^{\mathrm{T}}$ consisted of diphosphatidylglycerol, phosphatidylethanolamine, phosphatidylglycerol, phosphatidylcholine, phosphatidylinositol and an unknown glucosamine-containing phospholipid. Mycolic acid, which is the most important character shared by genera in the Corynebacterineae, could not be detected in strain DQS3-9A1 ${ }^{\mathrm{T}}$. The above chemical profiles therefore served to distinguish the tested strains from members of all genera in the Corynebacterineae (Table 1). Furthermore, distinctions could be made between strains DQS3-9A1 ${ }^{\mathrm{T}}$ and DQS3-9A2 and other members of the family Mycobacteriaceae in some signature nucleotide sites (Table 2). The DNA G + C content of strain DQS3-9A1 ${ }^{\mathrm{T}}$ was $60.04 \mathrm{~mol} \%$. Other biochemical characteristics of isolate DQS3-9 $\mathrm{Al}^{\mathrm{T}}$ are given in the genus description.

As a result, based on 16S rRNA gene sequence analysis, phenotypic characteristics and chemotaxonomic prop- 


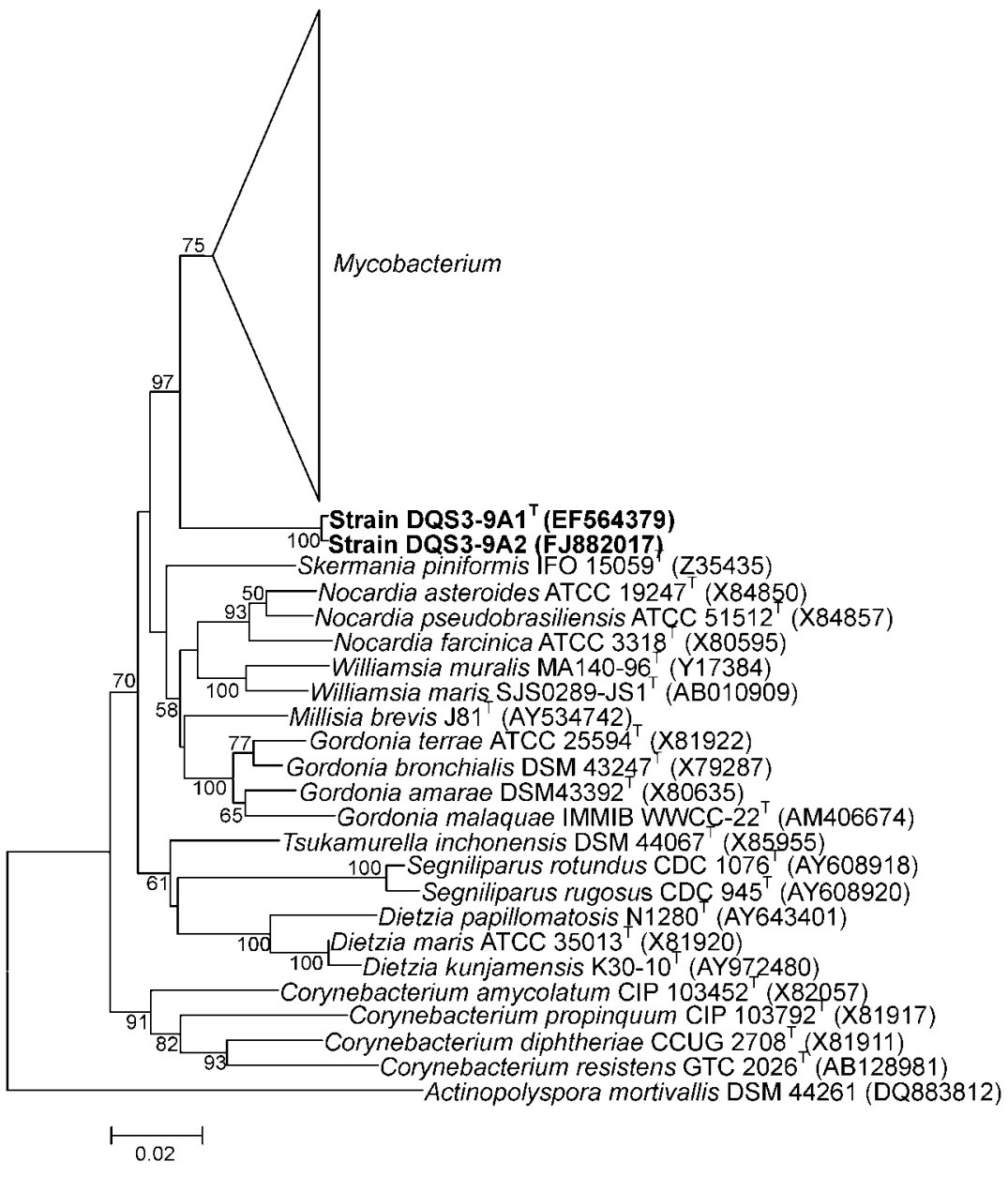

Fig. 2. Phylogenetic tree based on $16 \mathrm{~S}$ rRNA gene sequence analysis, reconstructed from evolutionary distances by using the neighbourjoining method, showing the phylogenetic positions of strains DQS3-9A $1^{\top}$ and DQS39A2 within the suborder Corynebacterineae. Bootstrap values are shown as percentages of 1000 replicates. Bar, 2 nucleotide substitutions per $100 \mathrm{nt}$. erties, it is clear that strains DQS3-9A1 ${ }^{\mathrm{T}}$ and DQS3-9A2 represent a novel genus within the family Mycobacteriaceae of the suborder Corynebacterineae, for which the name Amycolicicoccus subflavus gen. nov., sp. nov. is proposed.

\section{Description of Amycolicicoccus gen. nov.}

Amycolicicoccus [A.my.co.li.ci.coc'cus. Gr. pref. $a$ - not; N.L. n. acidum mycolicum mycolic acid; N.L. masc. n. coccus (from Gr. n. kokkos) a grain, berry; N.L. masc. n. Amycolicicoccus a coccus without mycolic acids].

Gram-positive, aerobic cocci without a flagellum. Spores are not present. Cell wall contains arabinose, galactose, glucose and xylose as major sugars, and alanine, glutamic acid, methionine and histidine as major amino acids. The polar lipids are diphosphatidylglycerol, phosphatidylethanolamine, phosphatidylglycerol, phosphatidylcholine, phosphatidylinositol and an unknown glucosamine-containing phospholipid. The predominant menaquinones are MK-8 and MK-7, and the major cellular fatty acids are $\mathrm{C}_{16: 0}, 10$-methyl $\mathrm{C}_{17: 0}, 10$-methyl $\mathrm{C}_{18: 0}$, summed feature 3, $\mathrm{C}_{15: 0}, \mathrm{C}_{17: 0}$ and $\mathrm{C}_{17: 1} \omega 8 \mathrm{c}$. Mycolic acid is absent. The type species is Amycolicicoccus subflavus.

\section{Description of Amycolicicoccus subflavus sp. nov.}

Amycolicicoccus subflavus (sub.fla'vus. L. masc. adj. subflavus yellowish).

Displays the following properties in addition to those described for the genus. Cells are $0.7-0.9 \times 0.9-1.05 \mu \mathrm{m}$ without a flagellum and colonies are dry, opaque and lightyellowish white on ASW agar. Growth occurs at $15-42{ }^{\circ} \mathrm{C}$ (optimum, $37^{\circ} \mathrm{C}$ ), $\mathrm{pH}$ 6.0-11.0 (optimum, $\mathrm{pH}$ 8.0) and in $1-12 \%(\mathrm{w} / \mathrm{v}) \mathrm{NaCl}$ [optimum, $8 \%(\mathrm{w} / \mathrm{v}) \mathrm{NaCl}$. Negative for hydrolysis of starch, gelatin, Tween 80 and casein, production of indole and DNase, aerobic nitrite reduction and anaerobic nitrate reduction. Positive for production of hydrogen sulfide and aerobic nitrate reduction. Cellobiose, dextrin, fucose, glucose, inositol, malic acid, maltose, mannose, mannitol, proline, sodium gluconate, sorbitol, sucrose and succinic acid are utilized as sole carbon and nitrogen sources, but alanine, arabinose, arginine, fructose, galactose, lactose, malonic acid, ribose, sorbose and xylose are not. Resistant to gentamicin $(10 \mu \mathrm{g})$, clindamycin $(2 \mu \mathrm{g})$, sulfamethoxazole $(300 \mu \mathrm{g})$, streptomycin $(300 \mu \mathrm{g})$ and amikacin $(30 \mu \mathrm{g})$. Sensitive to cephalothin $(30 \mu \mathrm{g})$, 
Table 1. Chemical and morphological properties of strain DOS3-9A $1^{\top}$ and other genera of the suborder Corynebacterineae

1, DQS3-9A1 ${ }^{\mathrm{T}} ; 2$, Mycobacterium; 3, Corynebacterium; 4, Segniliparus; 5, Dietzia; 6, Tsukamurella; 7, Skermania; 8, Millisia; 9, Gordonia; 10, Rhodococcus; 11, Nocardia; 12, Williamsia. Data from this study and Butler et al. (2005), Chun et al. (1997), Kämpfer et al. (1999), Li (2007), Rainey et al. (1995) and Soddell et al. (2006).

\begin{tabular}{|c|c|c|c|c|c|c|c|c|c|c|c|c|}
\hline Characteristic & 1 & 2 & 3 & 4 & 5 & 6 & 7 & 8 & 9 & 10 & 11 & 12 \\
\hline $\begin{array}{l}\text { Cell } \\
\text { morphology }\end{array}$ & Cocci & $\begin{array}{c}\text { Rods, occasionally } \\
\text { branched } \\
\text { filaments }\end{array}$ & $\begin{array}{l}\text { Pleomorphic } \\
\text { rods }\end{array}$ & Rods & $\begin{array}{l}\text { Short rods and } \\
\text { cocci }\end{array}$ & $\begin{array}{l}\text { Rods and } \\
\text { coccobacilli }\end{array}$ & $\begin{array}{l}\text { Mycelium } \\
\text { resembling } \\
\text { a pine tree }\end{array}$ & $\begin{array}{c}\text { Characteristic } \\
\text { rudimentary } \\
\text { right-angled } \\
\text { branching }\end{array}$ & $\begin{array}{l}\text { Rods and } \\
\text { cocci/ } \\
\text { moderately } \\
\text { branched } \\
\text { hyphae }\end{array}$ & $\begin{array}{l}\text { Rods to } \\
\text { extensively } \\
\text { branched } \\
\text { elements that } \\
\text { fragment }\end{array}$ & $\begin{array}{l}\text { Mycelium } \\
\text { that } \\
\text { fragments } \\
\text { into rods } \\
\text { and cocci }\end{array}$ & $\begin{array}{l}\text { Irregular } \\
\text { rods or } \\
\text { cocci }\end{array}$ \\
\hline Aerial hyphae & Absent & Usually absent & Absent & Absent & Absent & Absent & Present & Absent & Absent & Absent & Present & Absent \\
\hline Mycolic acid & Absent & Present & Present & Present & Present & Present & Present & Present & Present & Present & Present & Present \\
\hline $\begin{array}{l}\text { Predominant } \\
\text { menaquinone }\end{array}$ & MK-8 & MK-9 $\left(\mathrm{H}_{2}\right)$ & $\mathrm{MK}-8\left(\mathrm{H}_{2}\right)$ & $\mathrm{ND}$ & $\mathrm{MK}-8\left(\mathrm{H}_{2}\right)$ & MK-9 & $\begin{array}{r}\mathrm{MK}-8\left(\mathrm{H}_{4},\right. \\
\text { co-cycl. })\end{array}$ & $\mathrm{MK}-8\left(\mathrm{H}_{2}\right)$ & MK-9 $\left(\mathrm{H}_{2}\right)$ & $\mathrm{MK}-8\left(\mathrm{H}_{2}\right)$ & $\begin{array}{c}\text { MK-8 }\left(\mathrm{H}_{4},\right. \\
\text { co-cycl. })\end{array}$ & MK-9 $\left(\mathrm{H}_{2}\right)$ \\
\hline $\begin{array}{l}\text { Major polar } \\
\text { lipids }^{*}\end{array}$ & $\begin{array}{c}\text { DPG, PE, } \\
\text { PG, PC, } \\
\text { PI, } \\
\text { GluNU }\end{array}$ & $\begin{array}{c}\text { DPG, PE, PG, } \\
\text { PI, PIM }\end{array}$ & DPG, PG & $\mathrm{ND}$ & DPG, PE, PG & $\begin{array}{c}\text { DPG, PE, PI, } \\
\text { PIM }\end{array}$ & $\begin{array}{c}\text { DPG, PE, } \\
\text { PI, PIM }\end{array}$ & $\begin{array}{l}\text { DPG, PE, } \\
\text { PG, PI, PIM }\end{array}$ & $\begin{array}{r}\text { DPG, PE, } \\
\text { PI, PIM }\end{array}$ & $\begin{array}{l}\text { DPG, PE, } \\
\text { PIM }\end{array}$ & $\begin{array}{l}\text { DPG, PE, } \\
\text { PI, PIM }\end{array}$ & $\begin{array}{c}\text { DPG, PE, } \\
\text { PG, PI }\end{array}$ \\
\hline $\begin{array}{l}\text { Fatty acid } \\
\text { composition } \dagger\end{array}$ & $\begin{array}{l}\mathrm{S}, \mathrm{U}, \mathrm{T} \\
\mathrm{SF} 3\end{array}$ & $\mathrm{~S}, \mathrm{U}, \mathrm{T}$ & S, U末 & $S, U, T$ & $\mathrm{~S}, \mathrm{U}, \mathrm{T}$ & $S, U, T$ & $\mathrm{~S}, \mathrm{U}, \mathrm{T}$ & $\mathrm{S}, \mathrm{U}, \mathrm{T}$ & $\mathrm{S}, \mathrm{U}, \mathrm{T}$ & $\mathrm{S}, \mathrm{U}, \mathrm{T}$ & $S, U, T$ & $\mathrm{~S}, \mathrm{U}, \mathrm{T}$ \\
\hline $\begin{array}{l}\text { DNA G + C } \\
\text { content } \\
(\mathrm{mol} \%)\end{array}$ & 60.04 & $62-70$ & $51-67$ & $68-72$ & $66-73$ & $67-74$ & 67.5 & 64.7 & $63-69$ & $67-73$ & $64-72$ & $64-65$ \\
\hline
\end{tabular}

ND, No data.

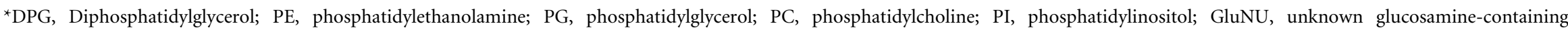
phospholipid; PIM, phosphatidylinositol mannosides.

$\uparrow S$, Saturated fatty acids; U, unsaturated fatty acids; T, tuberculostearic acid; SF3, summed feature $3(16: 1 \omega 7 c / 15$ iso $2 \mathrm{OH})$.

$\ddagger$ Tuberculostearic acid present in Corynebacterium ammoniagenes, Corynebacterium bovis, Corynebacterium minutissimum, Corynebacterium urealyticum and Corynebacterium variabilis. 
Table 2. Selected $16 \mathrm{~S}$ rRNA gene signature nucleotides detected for the family Mycobacteriaceae, strain DOS3-9A $1^{\top}$ and strain DOS3-9A2

The 16S rRNA gene sequences of all type strains belonging to the family Mycobacteriaceae were included in this analysis. The signatures given below for each group were chosen for their presence in more than $95 \%$ of the members of that group.

\begin{tabular}{|lccc|}
\hline Position(s) & Mycobacteriaceae & DQS3-9A1 $^{\text {T }}$ & DQS3-9A2 \\
\hline $293-304$ & G-U & - & G-C \\
307 & A & - & C \\
$316-337$ & U-G & - & C-G \\
468 & U & - & - \\
508 & U & C & C \\
$586-755$ & U-G & U-G & U-G \\
631 & G & G & G \\
$661-744$ & G-C & G-C & G-C \\
$662-743$ & U-G & C-G & C-G \\
$771-808$ & A-U & G-C & G-C \\
$824-876$ & C-G & U-A & U-A \\
$825-875$ & G-C & A-U & A-U \\
$837-849$ & G-U & U-A & U-A \\
843 & C & C & C \\
$1059-1198$ & U-A & C-G & C-G \\
\hline
\end{tabular}

ciprofloxacin $(5 \mu \mathrm{g})$, ceftriazone $(30 \mu \mathrm{g})$, penicillin (10 IU), clarithromycin $(15 \mu \mathrm{g})$, chloramphenicol $(30 \mu \mathrm{g})$, erythromycin $(15 \mu \mathrm{g})$, cefotaxime $(30 \mu \mathrm{g})$, vancomycin $(30 \mu \mathrm{g})$ and ampicillin $(10 \mu \mathrm{g})$. The DNA G+C content is $60.04 \mathrm{~mol} \%$.

The type strain, DQS3-9A1 $1^{\mathrm{T}}\left(=\mathrm{DSM} 45089^{\mathrm{T}}=\mathrm{CGMCC}\right.$ $4.3532^{\mathrm{T}}$ ), was isolated from an oil-polluted saline soil in Shengli Oilfield, eastern China. DQS3-9A2, isolated from the same site, is a reference strain.

\section{Acknowledgements}

The authors would like to thank G.-F. Zhao and B. Guo for their valuable help and discussion. This study was supported by the National High Technology Research and Development Program of China (863 Program) (no. 2007AA021303) and the National Natural Science Foundation of China (no. 30570033).

\section{References}

Butler, W. R., Floyd, M. M., Brown, J., Toney, S. R., Daneshvar, M., Cooksey, R. S., Carr, J., Steigerwalt, A. \& Charles, N. (2005). Novel mycolic acid-containing bacteria in the family Segniliparaceae fam. nov., including the genus Segniliparus gen. nov., with descriptions of Segniliparus rotundus sp. nov. and Segniliparus rugosus sp. nov. Int J Syst Evol Microbiol 55, 1615-1624.

Chun, J., Blackall, L. L., Kang, S. O., Hah, Y. C. \& Goodfellow, M. (1997). A proposal to reclassify Nocardia pinensis Blackall et al. as Skermania piniformis gen. nov., comb. nov. Int J Syst Bacteriol 47, 127-131.

Collins, M. D., Goodfellow, M. \& Minnikin, D. E. (1980). Fatty acid isoprenoid quinine and polar lipid composition in the classification of Curtobacterium and related taxa. J Gen Microbiol 118, 29-37.
Collins, M. D., Burton, R. A. \& Jones, D. (1988). Corynebacterium amycolatum sp. nov., a new mycolic acid-less Corynebacterium species from human skin. FEMS Microbiol Lett 49, 349-352.

Collins, M. D., Falsen, E., Akervall, E., Sjöden, B. \& Alvarez, A. (1998). Corynebacterium kroppenstedtii sp. nov., a novel corynebacterium that does not contain mycolic acids. Int J Syst Bacteriol 48, 1449-1454.

Collins, M. D., Hoyles, L., Foster, G. \& Falsen, E. (2004). Corynebacterium caspium sp. nov., from a Caspian seal (Phoca caspica). Int J Syst Evol Microbiol 54, 925-928.

De Ley, J., Cattoir, H. \& Reynaerts, A. (1970). The quantitative measurement of DNA hybridization from renaturation rates. Eur $J$ Biochem 12, 133-142.

Eguchi, M., Nishikawa, T. \& Macdonald, K. (1996). Responses to stress and nutrient availability by the marine ultramicrobacterium Sphingomonas sp. strain RB2256. Appl Environ Microbiol 62, 12871294.

Felsenstein, J. (1985). Confidence limits on phylogenies: an approach using the bootstrap. Evolution 39, 783-791.

Fernández-Garayzábal, J. F., Vela, A. I., Egido, R., Hutson, R. A., Lanzarot, M. P., Fernández-García, M. \& Collins, M. D. (2004). Corynebacterium ciconiae sp. nov., isolated from the trachea of black storks (Ciconia nigra). Int J Syst Evol Microbiol 54, 2191-2195.

Hall, V., Collins, M. D., Hutson, R. A., Lawson, P. A., Falsen, E. \& Duerden, B. I. (2003). Corynebacterium atypicum sp. nov., from a human clinical source, does not contain corynomycolic acids. Int $J$ Syst Evol Microbiol 53, 1065-1068.

Huß, V. A. R., Festl, H. \& Schleifer, K.-H. (1983). Studies on the spectrometric determination of DNA hybridisation from renaturation rates. Syst Appl Microbiol 4, 184-192.

Kämpfer, P., Anderson, M. A., Rainey, F. A., Kroppenstedt, R. M. \& Salonen, S. M. (1999). Williamsia muralis gen. nov., sp. nov., isolated from the indoor environment of a children's day care centre. Int J Syst Bacteriol 49, 681-687.

Kates, M. (1986). Techniques of Lipidology, 2nd edn. Amsterdam: Elsevier.

Kimura, M. (1980). A simple method for estimating evolutionary rates of base substitutions through comparative studies of nucleotide sequences. J Mol Evol 16, 111-120.

Komagata, K. \& Suzuki, K. (1987). Lipid and cell wall analysis in bacterial systematics. Methods Microbiol 19, 161-206.

Kumar, S., Tamura, K. \& Nei, M. (2004). MEGA3: integrated software for molecular evolutionary genetics analysis and sequence alignment. Brief Bioinform 5, 150-163.

Li, W. L. (2007). Corynebacterineae. In Actinomycete Systematic Principles, Methods and Practice, pp. 323-358. Edited by L. H. Xu, W. L. Li, Z. H. Liu \& C. L. Jiang. Beijing: Science Press.

Marmur, J. \& Doty, P. (1962). Determination of the base composition of deoxyribonucleic acid from its thermal denaturation temperature. J Mol Biol 5, 109-118.

Rainey, F. A., Klatte, S., Kroppenstedt, R. M. \& Stackebrandt, E. (1995). Dietzia, a new genus including Dietzia maris comb. nov., formerly Rhodococcus maris. Int J Syst Bacteriol 45, 32-36.

Saitou, N. \& Nei, M. (1987). The neighbor-joining method: a new method for reconstructing phylogenetic trees. Mol Biol Evol 4, 406425.

Soddell, J. A., Stainsby, F. M., Eales, K. L., Kroppenstedt, R. M., Robert, J., Seviour, R. J. \& Goodfellow, M. (2006). Millisia brevis gen. nov., sp. nov., an actinomycete isolated from activated sludge foam. Int J Syst Evol Microbiol 56, 739-744. 
Stackebrandt, E., Rainey, F. A. \& Ward-Rainey, N. L. (1997). Proposal for a new hierarchic classification system, Actinobacteria classis nov. Int J Syst Bacteriol 47, 479-491.

Thompson, J. D., Gibson, T. J., Plewniak, F., Jeanmougin, F. \& Higgins, D. G. (1997). The CLUSTAL_X windows interface: flexible strategies for multiple sequence alignment aided by quality analysis tools. Nucleic Acids Res 25, 4876-4882.

Wang, Y. N., Cai, H., Yu, S. L., Wang, Z. Y., Liu, J. \& Wu, X. L. (2007). Halomonas gudaonensis sp. nov., isolated from a saline soil contaminated by crude oil. Int J Syst Evol Microbiol 57, 911-915.

Wauters, G., Driessen, A., Ageron, E., Janssens, M. \& Grimont, P. A. D.

(1996). Propionic acid-producing strains previously designated as
Corynebacterium xerosis, C. minutissimum, C. striatum, and CDC group $\mathrm{I}$ and group $\mathrm{F}$ coryneforms belong to the species Corynebacterium amycolatum. Int J Syst Bacteriol 46, 653-657.

Williams, S. T., Goodfellow, M., Alderson, G., Wellington, E. M. H., Sneath, P. H. A. \& Sackin, M. J. (1983). Numerical classification of Streptomyces and related genera. J Gen Microbiol 129, 17431813.

Zumft, W. G. (1991). The denitrifying bacteria. In The Prokaryotes. A Handbook on the Biology of Bacteria: Ecophysiology, Isolation, Identification, Application, 2nd edn, pp. 554-582. Edited by A. Balows, H. G. Trüper, M. Dworkin, W. Harder \& K. H. Schleifer. New York: Springer. 